\title{
The Interactions of the Largest Subunit of RNA Polymerase II with Other Cellular Proteins: a Bioinformatic Approach
}

\author{
Abhijit Shukla ${ }^{1}$, Aparna Natarajan ${ }^{1}$, Sukesh \\ Bhaumik ${ }^{1}$, Hany A. El-Shemy ${ }^{2}$ and David \\ Lightfoot $^{1 *}$
}

'Southern Illinois University School of Medicine, Department of Biochemistry and Molecular Biology, Carbondale, IL 62901, USA

${ }^{2}$ Faculty of Agriculture Research Park (FARP) and Biochemistry Department, Faculty of Agriculture, University of Cairo, 12613 Giza, Egypt

Received 5 August 2008

Revised 27 September 2008

Accepted 8 October 2008

\begin{abstract}
The function of a protein is governed by its interaction with other proteins inside a cell. Therefore, it is important to identify the interacting partners of a particular protein to decipher its function. The protein interaction networks are generally determined by bioinformatic as well as experimental methodologies such as yeast two hybrid, mass spectrometry, immunoprecipitation, and fluorescence resonance energy transfer assays. Here, we have analyzed bioinformatically the interactions of Rpb1p (the largest subunit of RNA Polymerase II) with other proteins in yeast, using Cytoscape software and Biogrid/ Biomart database. We find that Rpb1p interacts with a large number of proteins involved in mRNA synthesis, processing, export, and other cellular processes. These results validate the application of such bioinformatic approach to determine the interactome for other cellular proteins.
\end{abstract}

Keywords: bioinformatics, protein interactions, Rbp1, yeast, human.

\begin{abstract}
Introduction
All cellular processes are carried out by the concerted actions of proteins through specific interaction networks. Therefore, protein function annotation has become an important area of research in post-genomic sequencing era. Thus, an understanding of various cellular processes demands elucidation of the protein-protein interaction networks within cell. Several experimental methodologies such as yeast two hybrid, mass spectrometry, immunoprecipitation, and fluorescence resonance energy transfer assays have been employed to decipher cellular
\end{abstract}

*For correspondence: ga4082@siu.edu

Tel. (618)-453-1797 protein-protein interactions. Based on these experimental studies, several bioinformatic tools have been developed to comprehensively analyze protein interaction networks of different cellular proteins. Here, we have used the Cytoscape software (Zhang et al., 2007) and Biogrid/ Biomart database to identify the interactions of the largest subunit of RNA Polymerase II (RNAPII), Rpb1, with other proteins in yeast. Such analysis has revealed a large number of primary interactions of Rpb1p with many proteins involved in the regulation of transcription, chromatin structure, DNA repair, and other cellular events as discussed below.

Rpb1 and its interactions with other RNAPII subunits The protein coding genes are transcribed into mRNA by RNAPII that is highly conserved from yeast to human. RNAPII is composed of 12 different subunits. These subunits are Rpb1, Rpb2, Rpb3, Rpb4, Rpb5, Rpb6, Rpb7, Rpb8, Rpb9, Rpb10, Rpb11, and Rpb12. Rpb1 is the largest subunit, and is essential to maintain the structural integrity of RNAPII. Moreover, it has $\mathrm{Mg}^{2+}$ dependent polymerase activity. The Rpb1 and Rpb2 subunits are located at the core of RNAPII with smaller subunits at the surface (Cramer et al., 2001, 2008; Bushnell and Kornberg, 2003; Cramer, 2004). Thus, Rpb1 interacts with several RNAPII subunits as also observed in this bioinformatic analysis (Fig. 1).

An important feature of Rpb1 is its c-terminal domain (CTD) that consists of multiple heptapeptide repeats (YSPTSPS) (Buratowski, 2003; Egloff and Murphy, 2008). Serine-2 and serine-5 (S-2 and S-5) of the heptapeptide in the CTD are phosphorylated and dephosphorylated during transcription by different kinases and phosphatases. Such phosphorylation status of Rpb1-CTD plays an important role in integrating various nuclear events through a variety of proteins involved in mRNA synthesis, processing, and export (Buratowski, 2003; Egloff and Murphy, 2008; Pandit et al., 2008). In addition, Rpb1 interacts with Mediator, general transcription factors and activator, chromatin modifying and remodeling factors, and several other proteins to maintain normal cellular functions. These interactions are discussed below.

\section{Interaction of Rpb1 with Mediator}

The yeast Mediator complex comprises of a large number of subunits that include Srb (suppressor of RNA polymerase B) proteins (Srb2, Srb4, Srb5, Srb6, Srb7, Srb8, Srb9, Srb10, Srb11), Med proteins (Med1, Med2, Med4, Med6, Med7, Med8 and Med11), and several other polypeptides (Pgd1, Cse1, Nut2, Rgr1, Gal11, Sin4, Rox3 and Soh1) (Kornberg, 2005). The core of the Mediator complex (known as core mediator complex) lacking Srb8, Srb9, Srb10 and Srb11 (or the Srb8-11 module) has a 


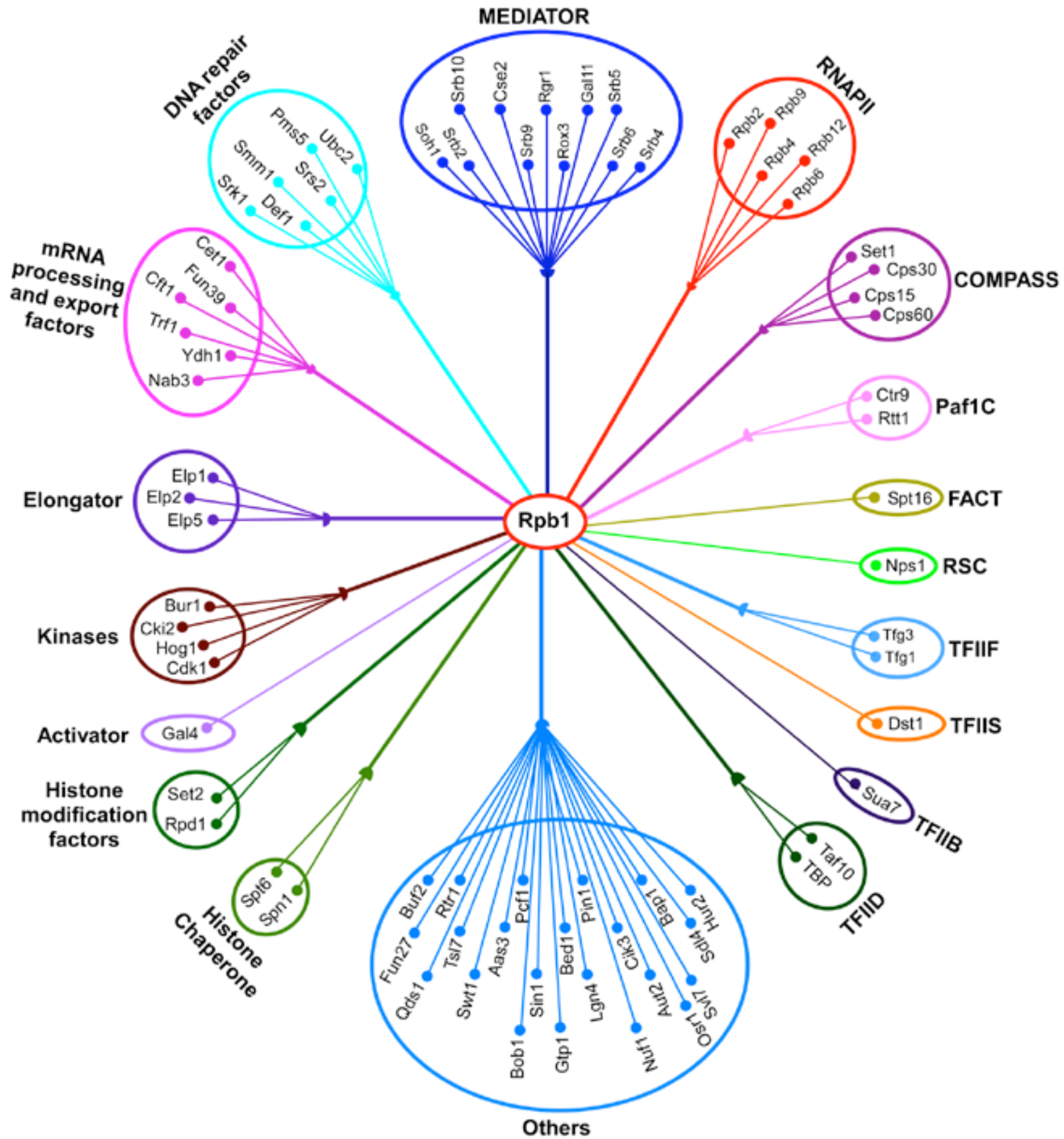

Fig. 1: The interaction of the largest subunit of RNAPII (Rpb1) with other cellular proteins in yeast as revealed by bioinformatic analysis.

stimulatory effect on transcription, whereas the whole Mediator complex represses transcription of a subset of genes (Borggrefe and Kornberg, 2002; Kornberg, 2005; Björklund and Gustafsson, 2005; Casamassimi and Napoli, 2007). Therefore, the Mediator complex plays an important role in transcriptional regulation as a co-activator or co-repressor through its interaction with several transcription factors. One important partner of Mediator in transcription machinery is RNAPII. Here, we have bioinformatically analyzed the interactions of the Mediator components with the largest subunit of RNAPII. This analysis shows that Rpb1 interacts with at least
11 subunits of the Mediator complex. These subunits are Cse2, Srb9, Rgr1, Gal11, Srb4, Srb5, Rox3, Srb2, Srb6, Soh1 and Srb10 as shown in Fig. 1. Likewise, Mediator components interact with other factors during transcription.

\section{Interaction of Rpb1 with COMPASS}

COMPASS is a histone methyltransferase in yeast (Miller et al., 2001). It methylates histone H3 on lysine-4 (H3K4) for transcriptional activation (Miller et al., 2001; Santos-Rosa et al., 2002; Liu et al., 2005; Shilatifard, 2006). COMPASS consists of 7 proteins (Cps60, Cps50, 
Cps40, Cps35, Cps30, Cps15 and Set1). The Set1 component of COMPASS boasts the enzymatic activity (Miller et al., 2001). Other COMPASS subunits play structural and functional roles to direct Set1 to perform its histone methylase activity (Shilatifard, 2006). COMPASS is recruited to the active genes by RNAPII, and thus methylates histone $\mathrm{H} 3 \mathrm{~K} 4$ in a transcription-dependent manner (Hampsey and Reinberg, 2003; Shilatifard, 2006). Consistent with these results, this bioinformatic analysis reveals that Rpb1 interacts with four subunits of COMPASS. These subunits are Set1, Cps15, Cps30 and Cps60 (Fig. 1).

\section{Interaction of Rpb1 with PAF}

Paf1C is a RNAPII-associated complex. In yeast, Paf1C is composed of Paf1, Cdc73, Ctr9, Rtf1, and Leo1 (Mueller and Jaehning, 2002; Hampsey and Reinberg, 2003). Basically, Paf1C interacts with histone methyltransferase, COMPASS, and histone $\mathrm{H} 2 \mathrm{~B}$ ubiquitinating enzymes (e.g. Rad6 and Bre1), and thus regulates histone covalent modification for stimulated transcription (Krogan et al., 2003a; Rosonina and Manley, 2005). Paf1C is co-transcriptionally recruited to active genes by RNAPII (Krogan et al., 2003a; Xiao and Strahl, 2005; Rosonina and Manley, 2005). Consistently, this bioinformatic analysis shows the interactions of the Ctr9 and Rtt1 subunits of Paf1C with the largest subunit of RNAPII (Fig. 1). In addition, Paf1C regulates mRNA 3' end formation through its interaction with mRNA cleavage and polyadenylation factors (Nordick et al., 2008).

\section{Interaction of Rpb1 with FACT}

FACT (Facilitates Chromatin Transcription) was identified as a factor required for transcription on chromatin template (Orphanides et al., 1998, 1999). FACT is composed of two subunits, namely, Spt16 and Pob3 in yeast. Lately, FACT has been implicated as an important elongation factor as a histone chaperone (Belotserkovskaya et al., 2003; Belotserkovskaya and Reinberg, 2004). Accordingly, FACT has been shown to travel with elongating RNAPII, and subsequently alters chromatin structure, thereby facilitating transcription (Belotserkovskaya et al., 2003; Belotserkovskaya and Reinberg, 2004; Saunders et al., 2003; Reinberg and Sims, 2006). These results are corroborated with this bioinformatic analysis for the interaction of FACT with the largest subunit of RNAPII (Fig. 1). In addition to its role in transcriptional elongation, FACT is recruited to gene promoter, and regulates transcriptional initiation (Mason and Struhl, 2003). Further, FACT has been shown to participate in regulation of DNA repair and replication (Wittmeyer and Formosa, 1997; Wittmeyer et al., 1999; Schlesinger and Formosa, 2000; Heo et al., 2008). Thus, FACT plays an important role in various cellular events.

\section{Interaction of Rpb1 with RSC}

RSC (remodels the structure of chromatin) is an abundant Swi/Snf-like chromatin remodeling complex with multiple subunits in yeast (Cairns et al., 1996). Unlike Swi/ Snf, RSC is essential for cellular viability. It has been implicated to activate as well as repress transcription (Moreira and Holmberg, 1999; Sudarsanam and Winston,
2000; Angus-Hill et al., 2001). Further, this bioinformatic analysis shows that the Nps1 component of RSC interacts with the largest subunit of RNAPII (Fig. 1). Thus, RSC appears to regulate transcription via its interaction with RNAPII. In addition to its role in transcription, RSC has been shown to play important role in DNA repair (van Attikum and Gasser, 2005; Chai et al., 2005; Shim et al., 2005).

\section{Interaction of Rpb1 with activator and general transcription factors}

In transcriptional activation, the activator stimulates formation of the pre-initiation complex (PIC) assembly which subsequently initiates transcription (Roeder, 2005; Thomas and Chiang, 2006). PIC is formed by the assembly of general transcription factors (e.g. TFIIA, TFIIB, TFIID, TFIIE, TFIIF, TFIIH, RNAPII, etc.). RNAPII is an important component of the PIC assembly, which initiates transcription in the presence of TFIIH. Further, previous studies (Smale and Kadonaga, 2003; Roeder, 2005; Thomas and Chiang, 2006) have implicated the interaction of RNAPII with activator and various general transcription factors during transcriptional initiation or activation as also seen in this bioinformatic analysis (Fig. 1).

\section{Interaction of Rpb1 with Elongator}

RNAPII associates with a variety of proteins/protein complexes during transcription elongation. (Shilatifard et al., 2003; Buratowski, 2003; Cramer, 2004; Buratowski, 2005; Shilatifard, 2006; Svejstrup, 2007). Elongator is one such component with six different subunits, namely Elp1, Elp2, Elp3, Elp4, Elp5 and Elp6 (Otero et al., 1999; Krogan and Greenblatt, 2001; Winkler et al., 2001; Li et al., 2001; Svejstrup, 2007). The Elp3 subunit has histone H4 acetyltransferase activity which facilitates transcriptional elongation following RNAPII-dependent association of Elongator with the body of gene (Wittschieben et al., 1999). These results are corroborated with this bioinformatic analysis that reveals that interacts of the Elp1, Elp2 and Elp5 subunits of Elongator with the largest subunit of RNAPII (Fig. 1). In addition to its role in transcriptional elongation, Elongator participates in cytoplasmic kinase signaling, exocytosis and tRNA modification (Holmberg et al., 2002; Rahl et al., 2005; Esberg et al., 2006; Jablonowski et al., 2006; Huang et al., 2005).

\section{Interaction of Rpb1 with Set2 and HDAC}

Histone covalent modifications have been associated with transcriptional regulation. Elongating RNAPII has been found to be associated with several covalent modification factors such as Set1 (COMPASS) and Elp3 (Elongator) as mentioned above. Further, elongating RNAPII has been implicated to regulate histone $\mathrm{H} 3$ K36 methylation at the body of gene by Set2 histone methylase (Li et al, , 2002; Krogan et al., 2003b; Hampsey and Reinberg, 2003; Keogh et al,, 2005; Carrozza et al., 2005). Set2 associates with the S-2 phosphorylated form of RNAPII that occurs towards the 3 ' end of the coding sequence, hence leading to histone H3 K36 methylation. Intriguingly, methylated-K36 on histone H3 leads to the recruitment of repressive $\mathrm{Rpd} 3(\mathrm{~S})$ complex with multiple 
subunits (e.g., Rpd3, Eaf3, Ume1, Sin3, Sap30, Sds3, Pho23, and Cti6/Rxt1) (Keogh et al,, 2005; Carrozza et al., 2005; Joshi and Struhl, 2005; Yang and Seto, 2008; Lee and Shilatifard, 2007). The chromodomain of Eaf3 is responsible for such recruitment (Joshi and Struhl, 2005; Carrozza et al., 2005; Keogh et al,, 2005). Rpd3 has a histone deacetylase (HDAC) activity that preferentially deacetylates acetylated-K on histone $\mathrm{H} 4$ (Keogh et al,, 2005; Carrozza et al., 2005; Joshi and Struhl, 2005). Such deacetylation has been implicated to repress cryptic transcriptional initiation. Thus, RNAPII regulates transcription by a fine tuning of acetylation/methylation marks via its interaction with Set2 and HDAC (Fig. 1).

Interaction of Rpb1 with histone chaperone proteins Chromatin presents a structural hindrance for the passage of elongating RNAPII. Therefore, molecular chaperones, which alter chromatin organization, become the rate limiting factors during transcriptional elongation. These chaperones are not only required to clear up the path for RNAPII during elongation, but also maintain the normal chromatin organization after transcription is completed. RNAPII has been shown to associate with molecular chaperones like FACT and Spt6 during transcriptional elongation (Krogan et al., 2002). Consistently, this bioinformatic analysis shows that histone chaperones interact with the largest subunit of RNAPII (Fig. 1). Further, this analysis reveals that Rpb1 interacts with Spn1 that is essential for the recruitment of Spt6 (Zhang et al., 2008). Intriguingly, Spt6 has also been shown to repress transcription of several genes (Compagnone and Osley, 1996). In addition, Spt6 has been implicated in mRNA processing, and export (Bucheli and Burtowski, 2005).

\section{Interaction of Rpb1 with mRNA processing and export factors}

Once the transcription is initiated, there are several proteins, which play a significant role in the processing of mRNA. Events, both at the $5^{\prime}$ end (such as capping) as well as $3^{\prime}$ end (e.g. mRNA cleavage and polyadenylation) involve several proteins. The recruitment as well as function of these proteins is tightly regulated. These proteins are shown to be co-transcriptionally recruited to the active genes by the elongating form of RNAPII (Zorio and Bentley, 2004; Bird et al., 2004; Buratowski, 2005; Mandel et al., 2008). In addition, RNAPII cotranscriptionally recruits mRNA export factors (Masuda et al., 2005; Buratowski, 2005). Consistently, this bioinformatic analysis shows the interaction of Rpb1 with the proteins involved in mRNA capping (Cet1), 3' end formation (Ctf1, Fun39, Nab3 and Ydh1) and export (Trf1) (Fig. 1). Thus, RNAPII appears to regulate mRNA processing and export via its interaction with proteins involved in these processes.

\section{Interaction of $\mathrm{Rpb1}$ with DNA repair factors}

Genomic DNA is constantly challenged by internal as well as external genotoxic agents. An extremely cytotoxic ramification is the lesion at the coding region of active gene which inhibits the passage of RNAPII, and subsequently leads to transcription coupled repair through its interaction with DNA repair and related factors (Lainé and Egly, 2006) as also revealed in this bioinformatic analysis (Fig. 1).

\section{Interaction of Rpb1 with protein kinases}

Biological processes in the cell are always tightly regulated. Phosphorylation/ dephosphorylation of proteins is one of the major ways the cell synchronize important cellular processes. The phosphorylation status of proteins is maintained by several distinct classes of kinases. Therefore, kinases play a critical role in regulation of many cellular events such as replication, transcription, cell cycle, protein degradation, etc. Further, kinase regulates transcription in a RNAPII-dependent manner. For example the largest subunit of RNAPII interacts with a number of protein kinases such as Cki2, Cdk1, Hog1 and Bur1 as shown in Fig. 1. These kinases are involved in diverse biological processes such as endocytic trafficking (Cki2), cell cycle regulation (Cdk1), osmoregulation (Hog1), and transcription (Bur1) (Hicke et al., 1998; Alepuz et al., 2003; Keogh et al., 2003; Harvey et al., 2005).

\section{Interaction of Rpb1 with other cellular proteins}

In addition to the above interactions, Rpb1 is correlated with several other processes through its interaction with various proteins, which are grouped as "others" in Fig. 1. For example, Rpb1 interacts with proteins involved in replication (e.g., Buf2, Bob1 and SId4), cytoskeleton organization (e.g., Lgn4, Nuf1 and Gtp1), and protein sorting (e.g., Svl7, Bed1 and Qds1). Further, Rpb1 interacts with some transcriptional regulatory factors such as CCR4-NOT (Fun27), proline isomerase (Pin1), Rtr1, Sin1, Aas3 and Bap1.

\section{Concluding remarks}

The function of a protein is dictated by its interaction with other cellular proteins, and, thus, understanding of the protein interaction networks is very crucial for protein function annotation. Several bioinformatic tools have been developed based on experimental data to analyze protein-protein interactions. One such bioinformatic tool is Cytoscape software. Using this software, we have analyzed the interactions of the largest subunit of RNAPII with other proteins in yeast to test the validity of this tool for cellular protein-protein interactions in general. We find that the largest subunit of RNAPII interacts with a large number of proteins involved in various stages of transcription, chromatin modification and remodeling, DNA repair, and other biological processes, consistent with experimental studies. Thus, our study validates the general applicability of this bioinformatic approach to analyze cellular protein-protein interactions.

\section{References}

Alepuz, P.M., de Nadal, E., Zapater, M., Ammerer, G., and Posas, F. (2003) Osmostress-induced transcription by Hot1 depends on a Hog1-mediated recruitment of the RNA Pol II. EMBO J., 22, 2433-2442.

Angus-Hill, M.L., Schlichter, A., Roberts, D., ErdjumentBromage, H., Tempst, P., and Cairns, B.R. (2001) A Rsc3/Rsc30 zinc cluster dimer reveals novel roles for 
the chromatin remodeler RSC in gene expression and cell cycle control. Mol. Cell 7, 741-751.

Belotserkovskaya, R., Oh, S., Bondarenko, V.A., Orphanides, G., Studitsky, V.M., and Reinberg, D. (2003) FACT facilitates transcription-dependent nucleosome alteration. Science 301, 1090-1093.

Belotserkovskaya, R., and Reinberg, D. (2004) Facts about FACT and transcript elongation through chromatin. Curr. Opin. Genet. Dev 14, 139-146.

Bird, G., Zorio, D.A., and Bentley, D.L. (2004) RNA polymerase II carboxy-terminal domain phosphorylation is required for cotranscriptional pre-mRNA splicing and 3'-end formation. Mol. Cell. Biol. 20, 8963-8969.

Björklund, S., and Gustafsson, C.M. (2005) The yeast Mediator complex and its regulation.Trends Biochem. Sci. 30, 240-244.

Borggrefe, T., Davis, R., Erdjument-Bromage, H., Tempst, P., and Kornberg, R.D. (2002) A complex of the Srb8, $-9,-10$, and -11 transcriptional regulatory proteins from yeast. J. Biol. Chem. 277, 44202-44207.

Bucheli, M.E, and Buratowski, S. (2005) Npl3 is an antagonist of mRNA $3^{\prime}$ end formation by RNA polymerase II. EMBO J. 24, 2150-2160.

Buratowski, S. (2003) The CTD code. Nat. Struct. Biol. 10, 679-680

Buratowski, S. (2005) Connections between mRNA 3' end processing and transcription termination. Curr. Opin. Cell Biol. 17, 257-261.

Bushnell, D.A., and Kornberg, R.D. (2003) Complete, 12-subunit RNA polymerase II at 4.1-A resolution: implications for the initiation of transcription. Proc. Natl. Acad. Sci. U.S.A. 100, 6969-6973.

Cairns, B.R., Lorchm Y., Lim Y., Zhangm M., Lacomism L., Erdjument-Bromage, H., Tempst, P., Du, J., Laurent, B., and Kornberg, R.D. (1996) RSC, an essential, abundant chromatin-remodeling complex. Cell 87, 1249-1260.

Carrozza, M.J., Li, B., Florens, L., Suganuma, T., Swanson, S.K., Lee, K.K., Shia, W.J., Anderson, S., Yates, J., Washburn, M.P., and Workman, J.L. (2005) Histone $\mathrm{H} 3$ methylation by Set2 directs deacetylation of coding regions by Rpd3s to suppress spurious intragenic transcription. Cell 123, 581-592.

H3 methylation by Set2 directs deacetylation of coding regions by Rpd3S to suppress spurious intragenic transcription. Cell 123, 581-592.

Casamassimi, A., and Napoli, C. (2007) Mediator complexes and eukaryotic transcription regulation: an overview. Biochimie 89, 1439-1446.

Chai, B., Huang, J., Cairns, B.R., and Laurent, B.C. (2005) Distinct roles for the RSC and Swi/Snf ATPdependent chromatin remodelers in DNA double-strand break repair. Genes Dev. 19, 1656-1661.

Cramer, P., Bushnell, D.A., and Kornberg RD. (2001) Structural basis of transcription: RNA polymerase II at 2.8 angstrom resolution. Science 292, 1863-1876.

Cramer, P. (2004) RNA polymerase II structure: from core to functional complexes. Curr. Opin. Genet. Dev. 14, 218-226.

Cramer, P., Armache, K.J., Baumli, S., Benkert, S., Brueckner, F., Buchen, C., Damsma, G.E., Dengl, S., Geiger, S.R., Jasiak, A.J., Jawhari, A., Jennebach, S.,
Kamenski, T., Kettenberger, H., Kuhn. C.D., Lehmann, E., Leike, K., Sydow, J.F., and Vannini, A. (2008) Structure of eukaryotic RNA polymerases. Annu. Rev. Biophys. 37, 337-352.

Compagnone-Post, P.A., and Osley, M.A. (1996) Mutations in the SPT4, SPT5, and SPT6 genes alter transcription of a subset of histone genes in Saccharomyces cerevisiae. Genetics 143, 1543-1554.

Egloff, S., and Murphy, S. (2008) Cracking the RNA polymerase II CTD code. Trends Genet. 6, 280-288.

Esberg, A., Huang, B., Johansson, M.J., and Bystrom, A.S. (2006) Elevated levels of two tRNA species bypass the requirement for Elongator complex in transcription and exocytosis. Mol. Cell 24, 139-148.

Hampsey, M. and Reinberg, D. ( 2003) Tails of intrigue: phosphorylation of RNA polymerase II mediates histone methylation. Cell 113, 429-432.

Harvey, S.L., Charlet, A., Haas, W., Gygi, S.P., and Kellogg, D.R. (2005) Cdk1-dependent regulation of the mitotic inhibitor Wee1. Cell 122, 407-420.

Heo, K., Kim, H., Choi, S.H., Choi, J., Kim, K., Gu, J., Lieber. M.R., Yang, A.S., and An, W. (2008) FACTmediated exchange of histone variant $\mathrm{H} 2 \mathrm{AX}$ regulated by phosphorylation of $\mathrm{H} 2 \mathrm{AX}$ and ADP-ribosylation of Spt16. Mol. Cell 30, 86-97.

Hicke, L., Zanolari, B., and Riezman, H. (1998) Cytoplasmic tail phosphorylation of the alpha-factor receptor is required for its ubiquitination and internalization. J. Cell Biol. 141, 349-358.

Holmberg, C., Katz, S., Lerdrup, M., Herdegen, T., Jaattela, M., Aronheim, A., and Kallunki, T. (2002) A novel specific role for IkB kinase complex-associated protein in cytosolic stress signaling. J. Biol. Chem. 277, 31918-31928.

Huang, B., Johansson, M.J., and Bystrom, A.S. (2005) An early step in wobble uridine tRNA modification requires the Elongator complex. RNA 11, 424-436.

Jablonowski, D., Zink, S., Mehlgarten, C., Daum, G., and Schaffrath, R. (2006) tRNAGlu wobble uridine methylation by Trm9 identifies Elongator's key role for zymocin-induced cell death in yeast. Mol. Microbiol. 59, 677-688.

Joshi, A.A., and Struhl, K. (2005) Eaf3 chromodomain interaction with methylated H3-K36 links histone deacetylation to Pol II elongation. Mol. Cell 20, 971978.

Keogh, M.C., Podolny, V., and Buratowski, S. (2003) Bur1 kinase is required for efficient transcription elongation by RNA polymerase II. Mol. Cell Biol, 19, 7005-7018.

Keogh, M.C., Kurdistani, S.K., Morris, S.A., Ahn, S.H., Podolny, V., Collins, S.R., Schuldiner, M., Chin, K., Punna, T., Thompson, N.J., Boone, C., Emili, A., Weissman, J.S., Hughes, T.R., Strahl, B.D., Grunstein, M., Greenblatt, J.F., Buratowski, S., and Krogan, N.J. (2005) Cotranscriptional set2 methylation of histone H3 lysine 36 recruits a repressive Rpd3 complex. Cell 123, 593-605.

Krogan, N.J., and Greenblatt, J.F. (2001) Characterization of a six-subunit holo-elongator complex required for the regulated expression of a group of genes in Saccharomyces cerevisiae. Mol. Cell Biol. 21, 82038212. 
Krogan, N.J., Kim,M., Ahn, S.H., Zhong, G., Kobor, M.S., Cagney, G., Emili, A., Shilatifard, A., Buratowski, S., and Greenblatt, J.F. (2002)RNA polymerase II elongation factors of Saccharomyces cerevisiae: a targeted proteomics approach. Mol. Cell Biol. 22, 6979-6992.

Krogan, N.J., Dover, J., Wood, A., Schneider, J., Heidt, J., Boateng, M.A., Dean, K., Ryan, O.W., Golshani, A., Johnston, M., Greenblatt, J.F., and Shilatifard, A. (2003a) The Paf1 complex is required for histone H3 methylation by COMPASS and Dot1p: linking transcriptional elongation to histone methylation. Mol. Cell 11, 721-729.

Krogan, N.J., Kim, M., Tong, A., Golshani, A., Cagney, G., Canadien, V., Richards, D.P., Beattie, B.K., Emili, A., Boone, C., Shilatifard, A., Buratowski, S., and Greenblatt, J. (2003b) Methylation of histone $\mathrm{H} 3$ by Set2 in Saccharomyces cerevisiae is linked to transcriptional elongation by RNA polymerase II. Mol. Cell Biol. 23, 4207-4218.

Kornberg, R.D. (2005) Mediator and the mechanism of transcriptional activation. Trends Biochem. Sci. 30, 235-239.

Lainé, J.P., and Egly, J.M. (2006) When transcription and repair meet: a complex system. Trends Genet. 22, 430-436.

Lee, J.S., and Shilatifard,A. (2007) A site to remember: H3K36 methylation a mark for histone deacetylation. Mutat. Res. 618, 130-134.

Li, J., Moazed, D., and Gygi, S.P. (2002) Association of the histone methyltransferase Set2 with RNA polymerase II plays a role in transcription elongation. J. Biol. Chem. 277, 49383-49388.

Li, Y., Takagi, Y., Jiang, Y., Tokunaga, M., ErdjumentBromage, H., Tempst, P., and Kornberg, R.D. (2001) A multiprotein complex that interacts with RNA polymerase II elongator. J. Biol. Chem. 276, 29628-29631.

Liu, C.L., Kaplan, T., Kim, M., Buratowski, S., Schreiber, S.L., Friedman, N., and Rando, O.J. (2005) Singlenucleosome mapping of histone modifications in $\mathrm{S}$. cerevisiae. PLoS Biol. 3, e328.

Mandel, C.R., Bai, Y., and Tong, L. (2008) Protein factors in pre-mRNA 3'-end processing. Cell Mol. Life Sci. 65, 1099-1122.

Mason, P.B. and Struhl, K. (2003) The FACT complex travels with elongating RNA polymerase $\|$ and is important for the fidelity of transcriptional initiation in vivo. Mol. Cell. Biol. 23, 8323-8333.

Masuda, S., Das, R., and Cheng, H., Hurt E., and Dorman, N., Reed R.(2005) Recruitment of the human TREX complex to mRNA during splicing. Genes Dev. 19, 1512-1517.

Miller, T., Krogan, N.J., Dover, J., Erdjument-Bromage, H., Tempst, P., Johnston, M., Greenblatt, J.F., and Shilatifard, A. (2001) COMPASS: a complex of proteins associated with a trithorax-related SET domain protein, Proc. Natl. Acad. Sci. U.S.A. 98, 12902-12907.

Moreira, J.M. and Holmberg, S. (1999) Transcriptional repression of the yeast $\mathrm{CHA} 1$ gene requires the chromatin-remodeling complex RSC. EMBO J. 18, 2836-2844.
Mueller, C.L. and Jaehning, J.A. (2002) Ctr9, Rtf1, and Leo1 are components of the Paf1/RNA polymerase II complex. Mol. Cell Biol. 22, 1971-1980.

Nordick, K., Hoffman, M.G., Betz, J.L., and Jaehning, J.A. (2008) Direct interactions between the Paf1 complex and a cleavage and polyadenylation factor are revealed by dissociation of Paf1 from RNA polymerase II. Eukaryot. Cell 7, 1158-1167.

Orphanides, G., LeRoy, G., Chang, C.H., Luse, D.S., and Reinberg, D. (1998) FACT, a factor that facilitates transcript elongation through nucleosomes. Cell 92, 105-116.

Orphanides, G., Wu, W.H., Lane, W.S., Hampsey, M., and Reinberg, D. (1999) The chromatin-specific transcription elongation factor FACT comprises human SPT16 and SSRP1 proteins. Nature 400, 284-288.

Otero, G., Fellows, J., Li, Y., de Bizemont, T., Dirac, A.M.G., Gustafsson, C.M., Erdjument-Bromage, H., Tempst, P., and Svejstrup, J.Q. (1999) Elongator, a multisubunit component of a novel RNA polymerase II holoenzyme for transcriptional elongation. Mol. Cell 3, 109-118.

Pandit, S., Wang, D., and Fu, X.D. (2008) Functional integration of transcriptional and RNA processing machineries. Curr. Opin. Cell Biol. 20, 260-265.

Rahl, P.B., Chen, C.Z., and Collins, R.N. (2005) Elp1p, the yeast homolog of the FD disease syndrome protein, negatively regulates exocytosis independently of transcriptional elongation. Mol. Cell 17, 841-853.

Reinberg, D. and Sims, R.J. 3rd. (2006) de FACTo nucleosome dynamics. J. Biol. Chem. 281, 2329723301.

Roeder R.G. (2005) Transcriptional regulation and the role of diverse coactivators in animal cells. FEBS Lett. 579, 909-915.

Rosonina, E. and Manley, J.L. (2005) From transcription to mRNA: PAF provides a new path. Mol. Cell 20, 167168.

Santos-Rosa, H., Schneider, R., Bannister, A.J., Sherriff, J., Bernstein, B.E., Emre, N.C., Schreiber, S.L., Mellor, J., and Kouzarides, T. (2002) Active genes are trimethylated at K4 of histone H3. Nature 419, 407-411.

Saunders, A., Werner, J., Andrulis, E.D., Nakayama, T., Hirose, S., Reinberg, D., and Lis, J.T. (2003) Tracking FACT and the RNA polymerase II elongation complex through chromatin in vivo. Science 301, 1094-1096.

Schlesinger, M.B, and Formosa, T. (2000) POB3 is required for both transcription and replication in the yeast Saccharomyces cerevisiae. Genetics 155, 15931606.

Shilatifard, A. (2006) Chromatin modifications by methylation and ubiquitination: implications in the regulation of gene expression, Annu Rev Biochem. 75, 243-269.

Shilatifard, A., Conaway, R.C., and Conaway, J.W. (2003) The RNA polymerase II elongation complex. Annu Rev Biochem. 72, 693-715.

Shim, E.Y., Ma, J.L., Oum, J.H., Yanez, Y., and Lee, S.E. (2005) The yeast chromatin remodeler RSC complex facilitates end joining repair of DNA double-strand breaks. Mol. Cell Biol. 25, 3934-3944 
Smale, S.T. and Kadonaga, J.T. (2003) The RNA polymerase II core promoter. Annu Rev Biochem. 72, 449-479.

Sudarsanam, P. and Winston, F. (2000) The Swi/Snf family nucleosome remodeling

complexes and transcriptional control. Trends Genet 16 , 345-351.

Svejstrup, J.Q. (2007) Elongator complex: how many roles does it play? Curr. Opin. Cell Biol. 19, 331-336

Thomas, M.C. and Chiang, C.M. (2006) The general transcription machinery and general cofactors. Crit. Rev. Biochem. Mol. Biol. 2006 41, 105-178.

van Attikum, H. and Gasser, S.M. (2005) ATP-dependent chromatin remodeling and DNA double-strand break repair. Cell Cycle 4, 1011-1014.

Winkler, G.S., Petrakis, T.G., Ethelberg, S., Tokunaga, M., Erdjument-Bromage, H., Tempst, P., and Svejstrup, J.Q. (2001) RNA polymerase II elongator holoenzyme is composed of two discrete subcomplexes. J. Biol. Chem. 276, 32743-32749.

Wittmeyer, J. and Formosa, T. (1997) The Saccharomyces cerevisiae DNA polymerase a catalytic subunit interacts with Cdc68/Spt16 and with Pob3, a protein similar to an HMG1-like protein. Mol. Cell. Biol. 17, 4178-4190.

Wittmeyer, J., Joss, L., and Formosa, T. (1999) Spt16 and Pob3 of Saccharomyces cerevisiae form an essential, abundant heterodimer that is nuclear, chromatin- associated, and copurifies with DNA polymerase $\alpha$. Biochemistry 38, 8961-8971.

Wittschieben, B.O., Otero, G., de Bizemont, T., Fellows, J., Erdjument-Bromage, H., Ohba, R., Li, Y., Allis, C.D., Tempst, P., and Svejstrup, J.Q. (1999) A novel histone acetyltransferase is an integral subunit of elongating RNA polymerase II holoenzyme. Mol. Cell 4, 123-128.

Xiao, T., Kao, C.F., Krogan, N.J., Sun, Z.W., Greenblatt, J.F., Osley, M.A., and Strahl, B.D. (2005) Histone $\mathrm{H} 2 \mathrm{~B}$ ubiquitylation is associated with elongating RNA polymerase II. Mol. Cell Biol. 25, 637-651.

Yang, X.J. and Seto, E. (2008) The Rpd3/Hda1 family of lysine deacetylases: from bacteria and yeast to mice and men. Nat. Rev. Mol. Cell 9, 206-218.

Zhang, S., Jin, G., Zhang, X.S., and Chen, L. (2007) Discovering functions and revealing mechanisms at molecular level from biological networks. Proteomics 7, 2856-2869.

Zhang, L., Fletcher, A.G., Cheung, V., Winston, F., and Stargell, L.A. (2008) Spn1 regulates the recruitment of Spt6 and the Swi/Snf complex during transcriptional activation by RNA polymerase II. Mol. Cell Biol. 28, 1393-403.

Zorio, D.A. and Bentley, D.L. (2004) The link between mRNA processing and transcription: communication works both ways. Exp. Cell Res. 296, 91-97. 


\section{Further Reading}

Caister Academic Press is a leading academic publisher of advanced texts in microbiology, molecular biology and medical research. Full details of all our publications at caister.com

- MALDI-TOF Mass Spectrometry in Microbiology Edited by: M Kostrzewa, S Schubert (2016) www.caister.com/malditof

- Aspergillus and Penicillium in the Post-genomic Era Edited by: RP Vries, IB Gelber, MR Andersen (2016) www.caister.com/aspergillus2

- The Bacteriocins: Current Knowledge and Future Prospects Edited by: RL Dorit, SM Roy, MA Riley (2016)

www.caister.com/bacteriocins

- Omics in Plant Disease Resistance Edited by: V Bhadauria (2016) www.caister.com/opd

- Acidophiles: Life in Extremely Acidic Environments Edited by: R Quatrini, DB Johnson (2016) www.caister.com/acidophiles

- Climate Change and Microbial Ecology: Current Research and Future Trend

Edited by: J Marxsen (2016)

www.caister.com/climate

- Biofilms in Bioremediation: Current Research and Emerging Technologies

Edited by: G Lear (2016)

www.caister.com/biorem

- Microalgae: Current Research and Applications Edited by: MN Tsaloglou (2016) www.caister.com/microalgae

- Gas Plasma Sterilization in Microbiology: Theory, Applications, Pitfalls and New Perspectives Edited by: H Shintani, A Sakudo (2016) www.caister.com/gasplasma

- Virus Evolution: Current Research and Future Directions Edited by: SC Weaver, M Denison, M Roossinck, et al. (2016) www.caister.com/virusevol

- Arboviruses: Molecular Biology, Evolution and Control Edited by: N Vasilakis, DJ Gubler (2016) www.caister.com/arbo

- Shigella: Molecular and Cellular Biology Edited by: WD Picking, WL Picking (2016) www.caister.com/shigella

-Aquatic Biofilms: Ecology, Water Quality and Wastewater Treatment

Edited by: AM Romaní, H Guasch, MD Balaguer (2016)

www.caister.com/aquaticbiofilms

- Alphaviruses: Current Biology

Edited by: S Mahalingam, L Herrero, B Herring (2016)

www.caister.com/alpha

- Thermophilic Microorganisms

Edited by: F Li (2015)

www.caister.com/thermophile
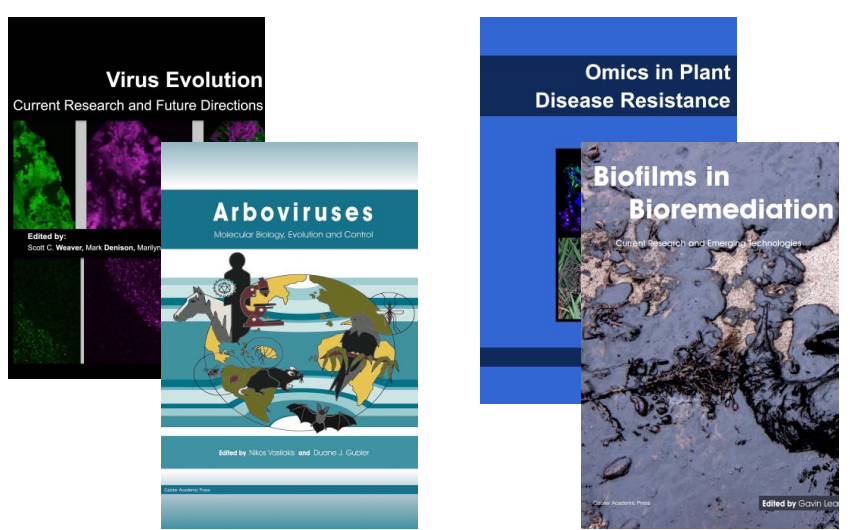
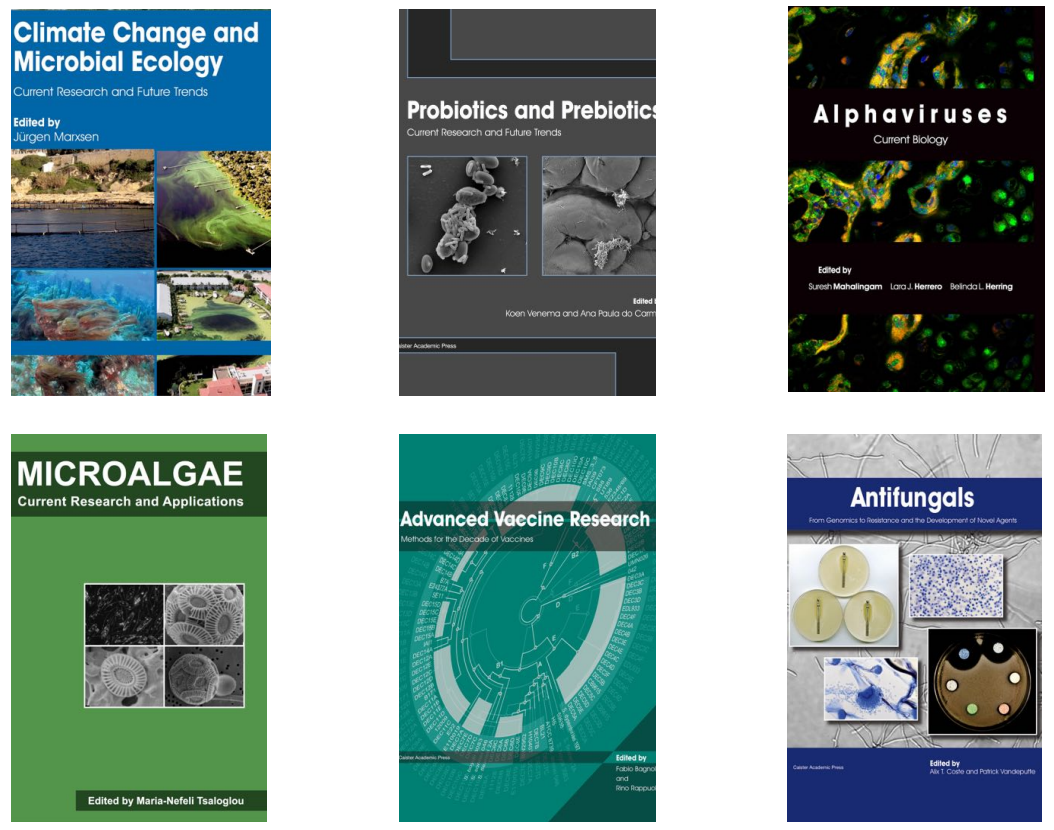

- Flow Cytometry in Microbiology: Technology and Applications Edited by: MG Wilkinson (2015) www.caister.com/flow

- Probiotics and Prebiotics: Current Research and Future Trends Edited by: K Venema, AP Carmo (2015) www.caister.com/probiotics

- Epigenetics: Current Research and Emerging Trends Edited by: BP Chadwick (2015) www.caister.com/epigenetics2015

- Corynebacterium glutamicum: From Systems Biology to Biotechnological Applications

Edited by: A Burkovski (2015)

www.caister.com/cory2

- Advanced Vaccine Research Methods for the Decade of Vaccines

Edited by: F Bagnoli, R Rappuoli (2015)

www.caister.com/vaccines

- Antifungals: From Genomics to Resistance and the Development of Novel Agents

Edited by: AT Coste, P Vandeputte (2015)

www.caister.com/antifungals

- Bacteria-Plant Interactions: Advanced Research and Future Trends Edited by: J Murillo, BA Vinatzer, RW Jackson, et al. (2015) www.caister.com/bacteria-plant

\section{- Aeromonas}

Edited by: J Graf (2015)

www.caister.com/aeromonas

- Antibiotics: Current Innovations and Future Trends

Edited by: S Sánchez, AL Demain (2015)

www.caister.com/antibiotics

- Leishmania: Current Biology and Contro Edited by: S Adak, R Datta (2015) www.caister.com/leish2

- Acanthamoeba: Biology and Pathogenesis (2nd edition) Author: NA Khan (2015)

www.caister.com/acanthamoeba2

- Microarrays: Current Technology, Innovations and Applications Edited by: Z He (2014)

www.caister.com/microarrays2

- Metagenomics of the Microbial Nitrogen Cycle: Theory, Methods and Applications

Edited by: D Marco (2014)

www.caister.com/n2 